\title{
USE OF GEOSPATIAL INFORMATION FOR DECISION-MAKING IN ENVIRONMENTAL MONITORING OF TEMPORARILY OCCUPIED TERRITORIES
}

\section{Butko I. M., Shamrai N. M.}

\section{INTRODUCTION}

During the conduct of hostilities on the territory of Donetsk and Lugansk regions, numerous environmental problems arise. These problems are mainly associated with the use of weapons and military equipment. Technogenic environmental factors (pollution) are classified according to the mechanism, degree, level, consequences and scale of impact. From the point of view of the mechanism, three types of pollution are distinguished on the environment, namely, of physical, chemical and biological nature ${ }^{1}$. Weapons and military equipment are capable of generating the most unsafe types of all three types.

Today, the soil surface of tens of thousands of temporarily occupied lands has been damaged by craters from mines and shells, damaged by tank tracks and heavy military equipment. It is also contaminated with oil products, which in large quantities can get into the ground from damaged military equipment and oil storage tanks, and then into the groundwater. Therefore, today it is advisable to collect a large amount of data and start analyzing such possible man-made disasters on the temporarily occupied territories.

To solve these problems, high-resolution satellites and Earth remote sensing systems are used. This is due to the possibility of unimpeded receipt of species information on objects and areas of interest, as well as the fact that the necessary information is obtained remotely. Also, the data obtained with the help of satellites and remote sensing systems on the territory of Donetsk and Luhansk regions and in Crimea are the only source of objective and operational information ${ }^{2}$. The information

${ }^{1}$ Каракеян В.И. Мониторинг загрязнения окружающей среды. Москва : Юрайт, 2016. 397 с.

${ }^{2}$ Fu W., Ma J., Chen P., Chen F. Remote Sensing Satellites for Digital Earth. In: Guo H., Goodchild M.F., Annoni A. (eds) Manual of Digital Earth. Springer, Singapore. 2020. P. 55-123. URL: https://doi.org/10.1007/978-981-32-9915-3_3. 
received in real time after processing, in turn, allows making management decisions in the temporarily occupied territories.

\section{The problem's prerequisites emergence and the problem's formulation}

Today, based on geospatial information, the following works can be performed $^{3,4}$ :

- to monitor the current state of the temporarily occupied territories and objects of interest on them (for example, military equipment, buildings, fuel tanks etc.);

- to create databases and catalogs about the temporarily occupied territory and objects of interest (especially about enterprises with potentially hazardous production);

- to analyze and predict the possible consequences of any actions in the temporarily occupied territories;

- to develop in advance comprehensive plans and decisions on environmental safety in the temporarily occupied territories; etc.

It is proposed to use the results of the analysis of geospatial information for making decisions on environmental monitoring of the temporarily occupied territories. It is especially important to assess the safety of further use of these territories.

It should be borne in mind what needs to be done and in the future to analyze not a "one-time" shooting of territories and objects of interest, but a group of images of one territory. This group of snapshots is then entered into the appropriate catalogs or databases. This will make it possible to evaluate events in dynamics and make management decisions in real time ${ }^{5}$.

${ }^{3}$ Бутко I.М. Використання інформації дистанційного зондування в інтересах реінтеграції тимчасово окупованих територій. Управління та адміністрування в умовах протидії гібридним загрозам національній безпец̧і: Матеріали I Bceукраїнської науково-практичної конференції (м. Київ, 7 грудня 2020 р.). Київ : ДУІТ. 2020. С. 111-113.

${ }^{4}$ Бутко I.М., Худов Г.В., Хижняк І.А. Використання інформації геоінформаційних систем для оцінки стану земельного фонду на тимчасово окупованих територіях. Наука, техніка і технологї: актуальні питання та дослідження : міжнар. наук-практ. конф., 12-13 бер. 2021 р. : тези допов. Прага, 2021. С. 13-17.

5 Khaustov I.A., Rylev S.S., Kovaleva E.N. Development and application of modern geographic information systems for monitoring the environmental status of objects. Proceedings of the Voronezh State University of Engineering Technologies. 2019. № 81 (4). P. 263-267. (In Russ.) URL: https://doi.org/10.20914/2310-12022019-4-263-267. 
Today, to make decisions on environmental monitoring of the temporarily occupied territories, modern information technologies can be used, which are a tool in the development of decision support systems ${ }^{6}$. Modern decision support systems conduct a thorough and objective analysis of the environmental monitoring task when making decisions.

Thus, decision support systems, collecting and analyzing a sufficiently large amount of information from the temporarily occupied territories, can influence the process of making managerial decisions. With the help of decision support systems, the choice of solutions can be carried out in poorly structured and certain unstructured tasks or in tasks that have many criteria ${ }^{7}$.

Decision support systems can be developed only if there is a knowledge base and a database. Knowledge bases contain inference rules, information about human experience and knowledge in a given subject area, which allow you to perform operations on these databases. Databases are a collection of geospatial data, defined calculations and studies ${ }^{8}$.

\section{The method of the decision-making support for environmental monitoring of temporarily occupied territories using geospatial information}

Geospatial information is received and stored in a central data warehouse. This store is part of the decision support systems hierarchical structure. The central data repository includes a knowledge base and a database $^{9}$. The knowledge base should contain attributive information about the temporarily occupied territories, objects in this territory and the tasks of environmental monitoring.

In the decision support system for the formal presentation of data in the knowledge base when developing solutions and recommendations for the problem of environmental monitoring of temporarily occupied

${ }^{6}$ Bidyuk P.I., Korshevnyuk L.O. Design of computer information systems for decision support, NTUU “KPI”, Kyiv. 2010. 340 p.

7 Hou J., Yuan Y., Peitao W., Zhiyuan R., Xiaojuan L. Development of a decision support system for tsunami evacuation: application to the Jiyang District of Sanya city in China. Nat. Hazards Earth Syst. Sci. 2017. P. 335-343.

${ }^{8}$ Butko I. The Use of Geospatial Information by Public Authorities to Support the Decision Making of Management. Advanced Information Systems. 2021. № 5 (1). P. 39-44. DOI: https://doi.org/10.20998/2522-9052.2021.1.05.

${ }^{9}$ Terelyansky P.V. Decision support systems. Experience of design, Volga State Techn. Univ, Volgograd. 2009. 127 p. 
territories, we will choose the methods of category theory ${ }^{10}$. This is due to the fact that it is necessary to take into account the representation of knowledge in the knowledge base by ontological models when developing a decision support system. These allow using such mathematical constructions as statements, predicates, etc. in the form of category objects $^{11}$.

In [10] it is proposed to designate the content of knowledge base in the form of a multilevel model - categories of small categories - Cat which are connected by functors $-F$.

To develop a sequence of actions for a decision support method for environmental monitoring of temporarily occupied territories using geospatial information, we use the results of the work [10].

The highlighted category Cat consists of two small categories $\left\{O b_{1}^{C a t}, O b_{2}^{C a t}\right\} \subset C a t$, which are interpreted as follows:

$-O b_{1}^{C a t} \equiv K_{1}-$ a set of laws and regulations in the field of environmental monitoring of temporarily occupied territories;

$-O b_{2}^{C a t} \equiv K_{2}-$ a set of schemes for solving problems in environmental monitoring of temporarily occupied territories. These task solving schemes can be selected in accordance with the criteria specified by the operator.

The objects of categories $K_{1}$ and $K_{2}$ presented in the knowledge base allow for a sequential selection of the law and model. Then bring them into the following compliance (1) [10]:

$$
G \subseteq O b\left(K_{1}\right) \times O b\left(K_{2}\right) .
$$

In Fig. 1 presented multilevel commutative diagram of relations between categories $K_{1}$ and $K_{2}$ and objects of small categories $O b_{1}^{C a t}$ and $\mathrm{Ob}_{2}^{\mathrm{Cat}}$ when solving tasks in a decision support system.

10 Кухар М.А. Алгоритм функціонування системи підтримки прийняття рішень в земельних відносинах. Інформатика та математичні методи в моделюванні. 2017. № 7 (4). С. 325-332.

11 Бутко I.M. Формалізація технології використання геопросторових структур в системах обробки геопросторової інформації. Системи управління, навігаціï та зв'язку. 2021. № 1 (63). С. 17-22. DOI: https://doi.org/ 10.26906/SUNZ.2021.1.017. 


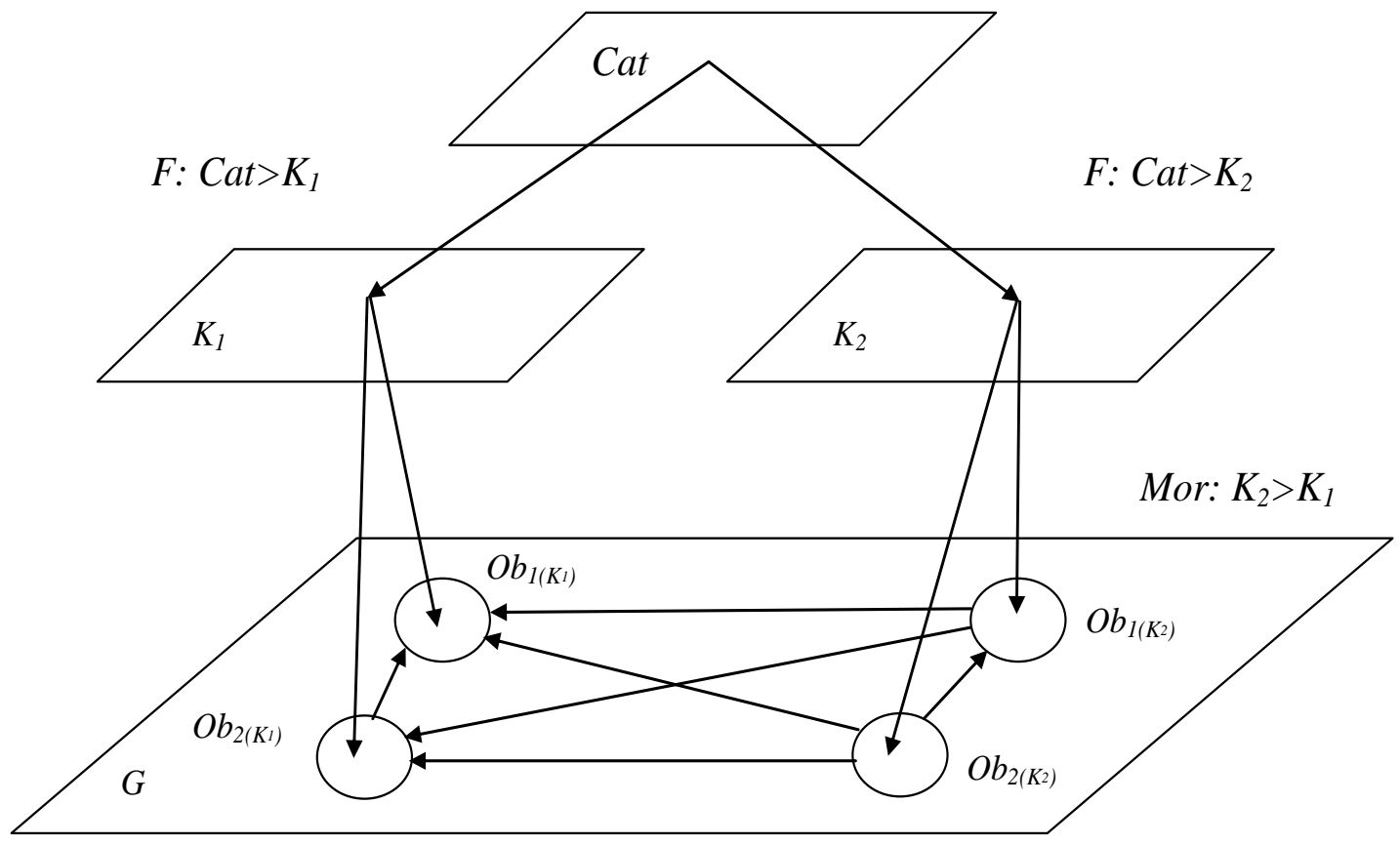

Fig. 1. Multilevel commutative diagram of relations between categories $K_{1}$ and $K_{2}$ and objects of small categories $O b_{1}^{C a t}$ and $O b_{2}^{C a t}$ when solving tasks in a decision support system ${ }^{12}$

The reflection of real tasks in the environmental monitoring of temporarily occupied territories is the interaction between objects of categories $K_{1}$ and $K_{2}$, in which ${ }^{13}$ :

- $\sum \operatorname{Mor}\left(K_{1}, K_{2}\right)$ - a set of morphisms between small categories $K_{1}$ and $K_{2}$;

- $\left\{O b_{1}^{11}, \ldots,\left\{O b_{1}^{12}, \ldots,\left\{O b_{1}^{14}, \ldots, O b_{m}^{14}\right\}\right\}\right\} \subset K_{1}-$ is the boundary of the sets of the categorical model $K_{1}$, where $O b_{1}^{11}, O b_{1}^{12}, O b_{1}^{13}, O b_{1}^{14}$ are laws, sections, chapters and articles of legislation in the field of environmental monitoring, respectively;

- $\quad M=\left\{m_{1}, m_{2}, \ldots m_{\xi}\right\}, \quad \xi=\overline{1, h}-$ a set of schemes for solving tasks in the field of environmental monitoring;

- $\quad D=\left\{d_{j}\right\}, j=\overline{1, y}-$ a set of public authorities;

12 Кухар М.А. Алгоритм функціонування системи підтримки прийняття рішень в земельних відносинах. Інформатика та математичні методи в моделюванні. 2017. № 7 (4). С. 325-332.

${ }^{13}$ Butko I. The Use of Geospatial Information by Public Authorities to Support the Decision Making of Management. Advanced Information Systems. 2021. № 5 (1). P. 39-44. 
- $S=\left\{s_{i}\right\}, i=\overline{1, t}-$ a set participants in the tasks of environmental monitoring of the temporarily occupied territories;

- $Z=\left\{z_{p}\right\}, p=\overline{1, l}-$ a set of tasks of environmental monitoring of the temporarily occupied territories;

$$
\text { - } G \subseteq(D \times S \times Z)=\left\{\left(d_{j}, s_{i}, z_{p}\right) \mid d_{j} \in D, s_{i} \in S, \quad z_{p} \in Z\right\} \quad \text { - relations }
$$
between public authorities, participants in the tasks of environmental monitoring of temporarily occupied territories and tasks of environmental monitoring;

- $\quad G=\left\{g_{q}\right\}, q=\overline{1, \delta}-$ a lot of relations between public authorities, participants in the tasks of environmental monitoring of temporarily occupied territories and tasks of environmental monitoring;

- $m_{h}=\left\langle s_{h}, d_{q}, z_{h}, g_{h}\right\rangle$ - scheme for solving tasks in environmental monitoring of temporarily occupied territories.

Based on knowledge models of objects and subjects of environmental relations, a decision support process can be carried out. This process is presented in the form of a sequence of actions of the method of supporting the adoption of managerial decisions by public authorities when carrying out work in environmental monitoring of temporarily occupied territories using geospatial information. In Fig. 2 this sequence of actions is presented.

The sequence of actions for the implementation of the decision-making support process by public authorities in environmental monitoring of temporarily occupied territories using geospatial information is as follows ${ }^{14}$ :

Stage I. Start of the method.

At this stage, the necessity and feasibility of using a decision support system for solving the urgent task of environmental monitoring is determined. The transition to the next stage is carried out when deciding on the advisability of using a decision support system to solve the task.

Stage II. Formulation of the problem.

At this stage, a user request is formed in accordance with the attribute data from the database. This is where the definition of constraints that make it possible to separate the acceptable options from the unacceptable ones, and the criteria that contribute to the selection of the best suitable option for solving environmental tasks, takes place.

${ }^{14}$ Butko I. The Use of Geospatial Information by Public Authorities to Support the Decision Making of Management. Advanced Information Systems. 2021. № 5 (1). P. 39-44. 


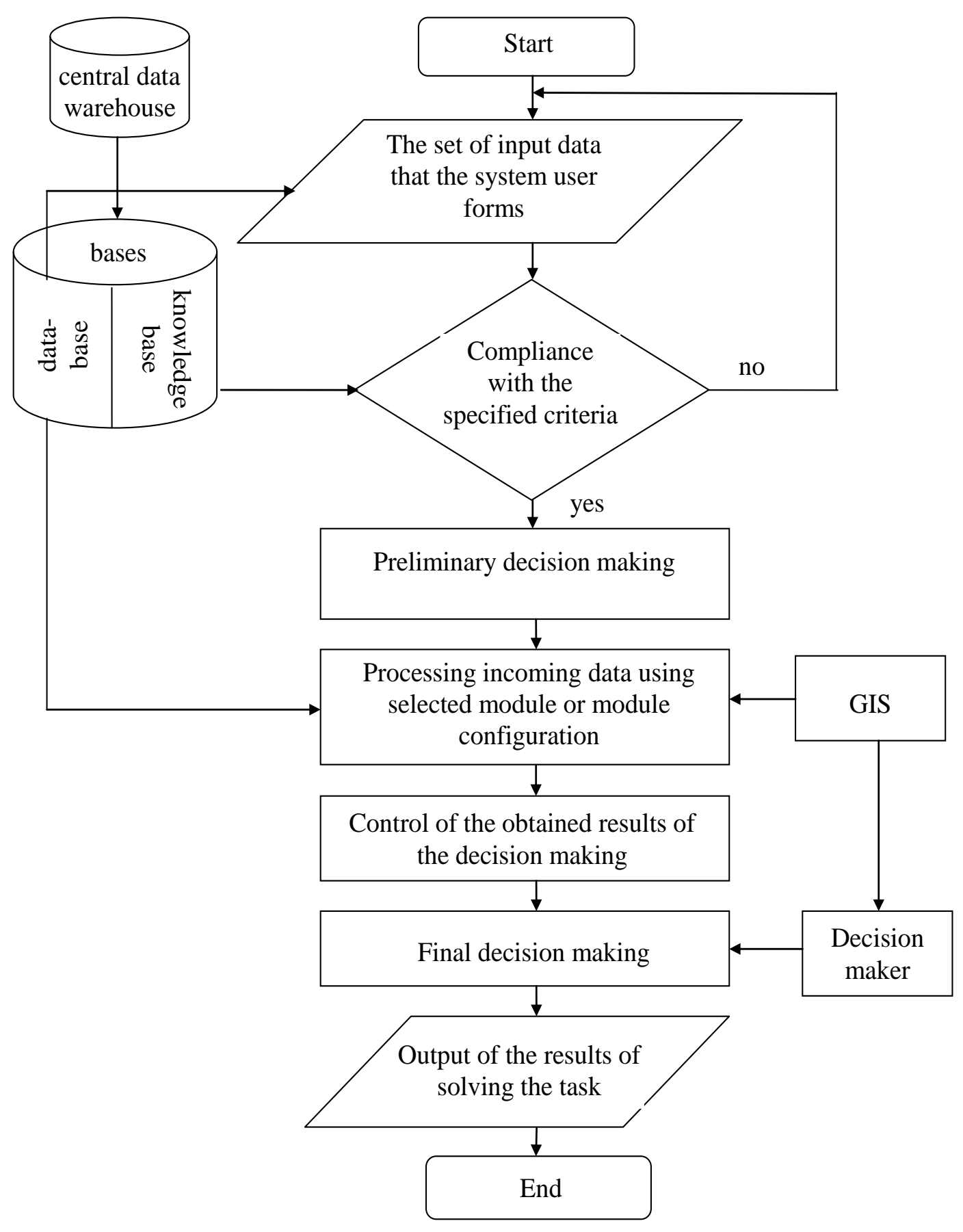

Fig. 2. The sequence of actions of the method of the decision-making support process by public authorities in environmental monitoring of temporarily occupied territories using geospatial information

Stage III. Checking the fulfillment of the condition.

Checking whether the request data meets the processing criteria and whether it can be used by one of the knowledge base models. If the request data does not meet the criteria for their processing, the transition to stage II of formulation of the task statement is carried out to correct the original request. 
Stage IV. Search and selection of a module (configuration of modules).

At this stage, the search for a module (configuration of modules) of the decision support system is performed, which is supplied to service the problem being solved. As well as the operator's choice of modules (configuration of modules) for solving task. This is provided on the basis of ontological models that are presented in the knowledge base.

Due to the fact that for the formal representation of data in the knowledge base, it is proposed to use the theory of categories in the work, this representation can be considered as an oriented multigraph. In this multigraph, the vertices are objects of categories, and the arrows are morphisms for solving the problem of supporting managerial decisionmaking in environmental monitoring. Then, on such a multigraph, you can use the methods of swarm intelligence. These methods relate to the field of artificial intelligence, and are based on modelling the social behavior of living organisms ${ }^{15}$.

Stage V. Processing incoming data.

Processing is performed using the module selected at the previous stage (configuration of modules). Data processing is carried out using auxiliary software. It is proposed to use remote sensing data as input data.

Stage VI. Making a preliminary decision.

The control of the obtained decision-making results is carried out.

Stage VII. Making the final decision.

The final decision is made by a special person who makes decisions using remote sensing data. And presentation of results in a form and format that is convenient for their analysis by the user.

Stage VIII. Output of the results of solving the task.

Stage IX. The end of the method.

The result of the method is the final set of options for management decisions for decision-making in environmental monitoring of temporarily occupied territories.

The decision support system that implements the proposed method produces a finite set of options for managerial decisions and criteria for solving the task in the environmental monitoring of temporarily occupied territories.

A decision is considered to be a reasonable set of actions on the part of a decision-maker aimed at an object of interest or a control system. It is

15 Лубко Д.В., Шаров С.В. Методи та системи штучного інтелекту : навчальний посібник. Мелітополь : ФОП Однорог Т.В., 2019. 264 с. 
makes it possible to bring this object or system to the desired state or achieve a set goal.

Let us consider in detail the proposals for data processing, which are performed at stage $\mathrm{V}$. This processing is carried out using auxiliary software. It is proposed to use remote sensing data as input data.

\section{The methods of swarm intelligence of processing geospatial information for use in a decision support system for decision-making in environmental monitoring of temporarily occupied territories}

It is proposed to use the methods of swarm intelligence as an auxiliary software for processing geospatial information, namely: an improved method of an artificial bee colony ${ }^{16}$ and an improved method based by the ant algorithm optimization ${ }^{17}$.

The result of the work of these methods is the selected objects of interest, which are input data into the database of the proposed decision support method for environmental monitoring of temporarily occupied territories using geospatial information.

For the task of detecting compact objects, for example, equipment, buildings, it is better to use the method of an artificial bee colony. For the task of detecting extended objects, for example, roads, bridges, fortifications, it is better to use a method based by the ant algorithm optimization. In the case when nothing is known in advance about the terrain and objects of interest, then it is proposed to use these methods in parallel.

Consider the sequence of actions of the method of processing geospatial images by the artificial bee colony (Fig. 3$)^{18}$.

16 Ruban I, Khudov H., Makoveichuk O., Khizhnyak I., Khudov V., Podlipaiev V., Shumeiko V., Atrasevych O., Nikitin A., Khudov R. Segmentation of opticalelectronic images from on-board systems of remote sensing of the Earth by the artificial bee colony method. Eastern-European Journal of Enterprise Technologies. 2019. Vol. 98. № 2/9. P. 37-45. DOI: https://doi.org/10.15587/1729-4061. 2019.161860.

${ }^{17}$ Ruban I., Khudov H., Makoveichuk O., Chomik M., Khudov V., Khizhnyak I., Podlipaiev V., Sheviakov Y., Baranik O., Irkha A. Construction of methods for determining the contours of objects on tonal aerospace images based on the ant algorithms. Eastern-European Journal of Enterprise Technologies. 2019. Vol. 101. № 5/9. P. 25-34. DOI: https://doi.org/10.15587/1729-4061.2019.177817.

${ }^{18}$ Ruban I, Khudov H., Makoveichuk O., Khizhnyak I., Khudov V., Podlipaiev V., Shumeiko V., Atrasevych O., Nikitin A., Khudov R. Segmentation of opticalelectronic images from on-board systems of remote sensing of the Earth by the artificial bee colony method. Eastern-European Journal of Enterprise Technologies. 2019. Vol. 98, № 2/9. P. 37-45. DOI: https://doi.org/10.15587/1729-4061.2019.161860. 


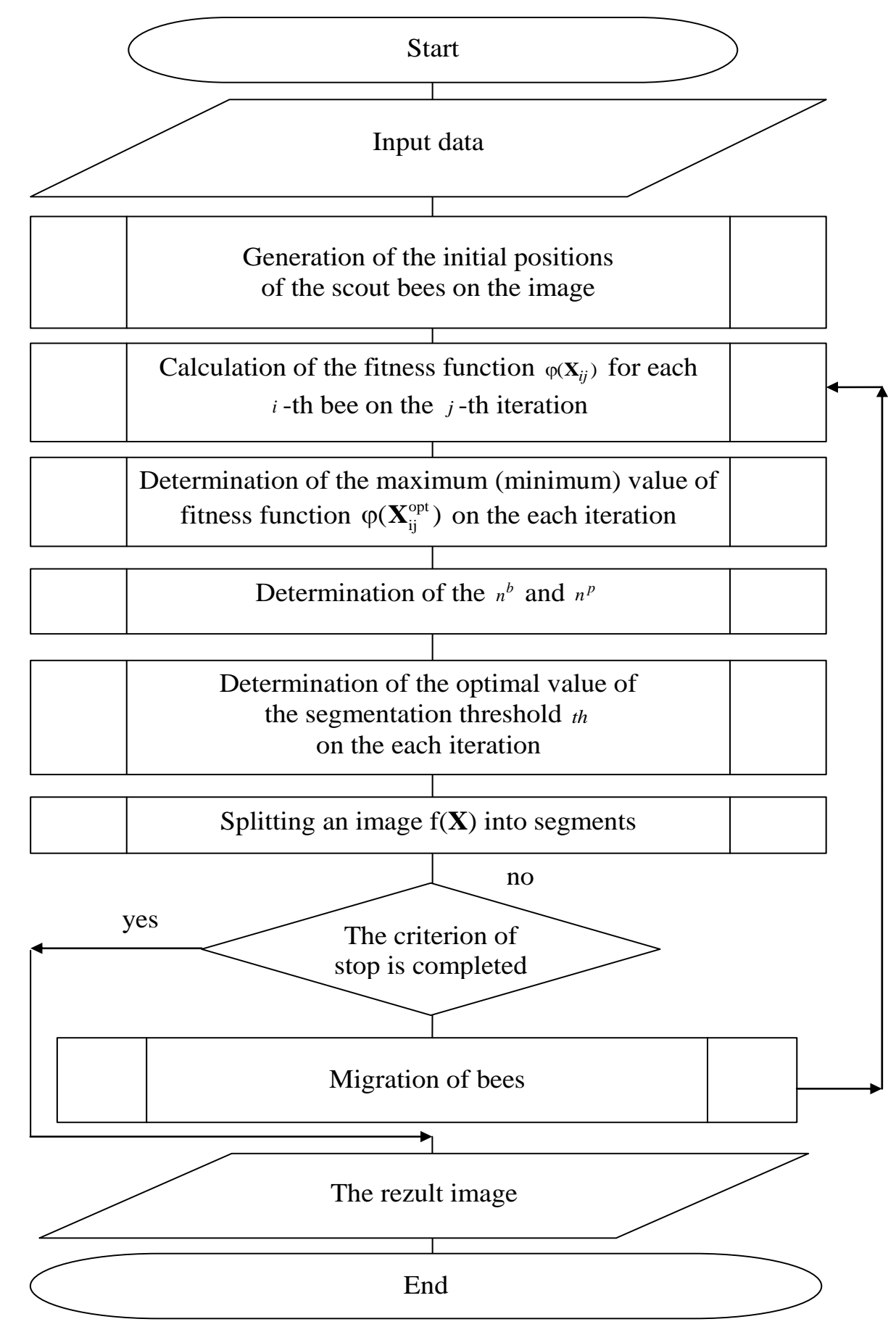

\section{Fig. 3. The sequence of actions of the method of processing geospatial images by the artificial bee colony}

Stage I. Start of the method.

Stage II. Input data. This is the original geospatial image, the total number of bees, the number of scout bees, the number of robotic bees surrounded by the best and most promising positions, the number of migrating bees, the size of the environment of the best and most promising positions. 
Stage III. Generation of the initial positions of the bees on the original geospatial image. Generation of initial positions is performed only at the first iteration of the method using a random number generator.

Stage IV. Calculation of the fitness function $\varphi\left(\mathbf{X}_{i j}\right)$ for each $i$-th bee on the $j$-th iteration.

Stage V. Determination of the perspective positions and the best positions of bees, taking into account the value of $\varphi\left(\mathbf{X}_{i j}\right)$ the fitness function of each $i$-th bee.

Stage VI. Determination of the optimal value of the segmentation threshold on the each iteration.

Stage VII. Splitting an image into segments.

Stage VIII. Verification of the fulfillment of the criteria for stopping work. The stopping criterion can be:

- reaching the maximum permissible number of iterations,

- search for the necessary solution,

- no significant improvement in the value of the fitness function for a certain number of iterations.

If the criterion for stopping the work of the method is met, then the resulting image is displayed and the work of the method ends. otherwise, the transition to the next stage IX takes place. At stage IX, the position of the bees is changed and after that the fitness function is calculated for the new positions of the bees at the next iteration of the iterative process of the method.

Stage IX. Migration of bees.

Stage $\mathbf{X}$. The output of the rezult image.

Stage XI. The end of the method.

The result of the image processing method of the improved method based by by the artificial bee colony is the following:

- determination of the coordinates of the position of bees, at which the value of the objective function will be maximum or minimum;

- determination of the optimal value of the segmentation threshold.

A visual assessment of the work of this method makes it easy to identify objects in the resulting image. This method of processing geospatial images by the artificial bee colony selects areas on the original geospatial image.

Consider the sequence of actions of the method of processing geospatial images by the ant colony optimization (Fig. 4) ${ }^{19}$.

${ }^{19}$ Ruban I., Khudov H., Makoveichuk O., Chomik M., Khudov V., Khizhnyak I., Podlipaiev V., Sheviakov Y., Baranik O., Irkha A. Construction of methods for 


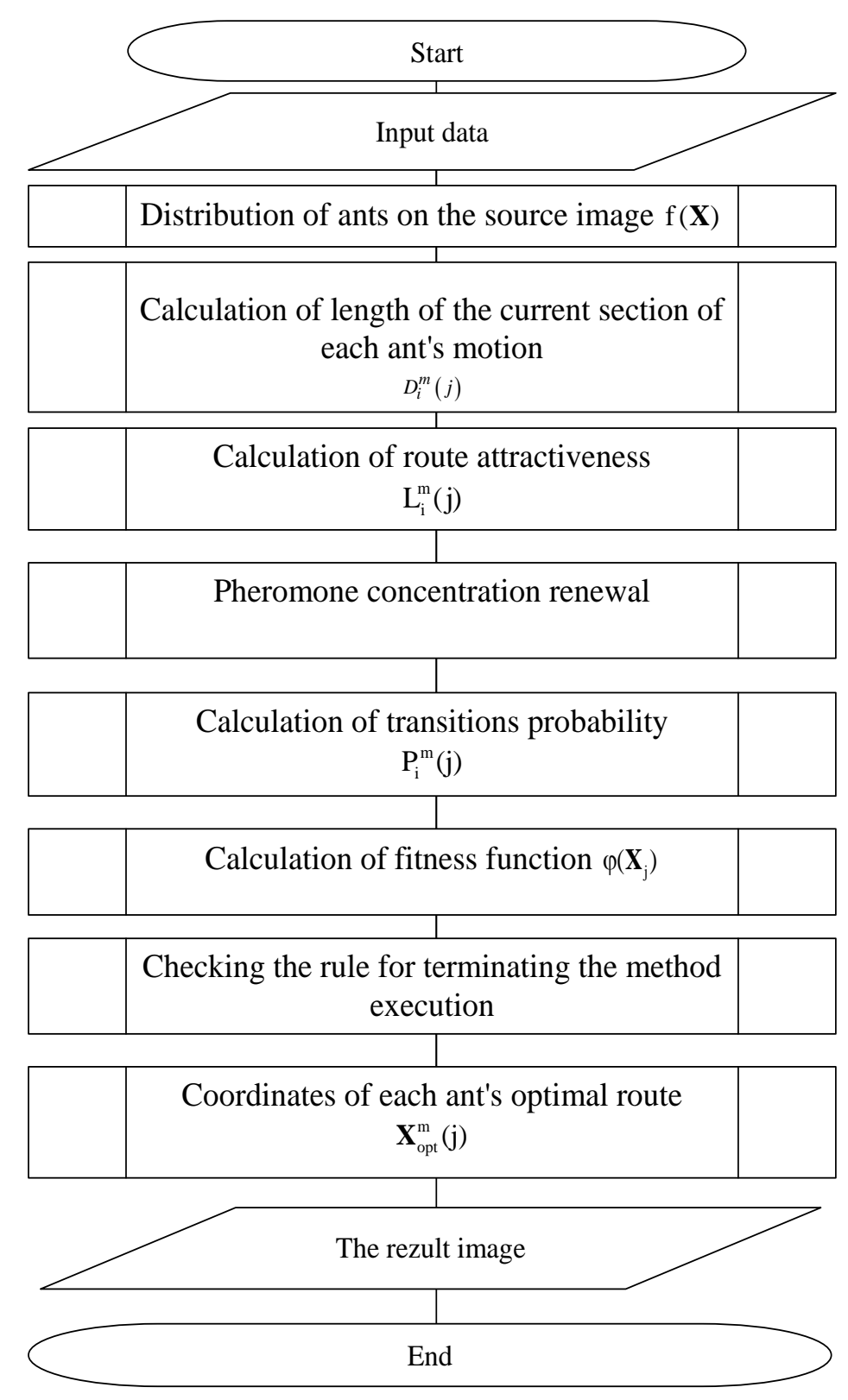

\section{Fig. 4. The sequence of actions of the method of processing geospatial images by the ant colony optimization}

Stage I. Start of the method.

Stage II. Input data. This is the original geospatial image, the total number of ants, the parameter that sets the "greed" of the method, the parameter that sets the weight of the pheromone of ants, the rate of evaporation of pheromone, the amount of pheromone on the route sections.

determining the contours of objects on tonal aerospace images based on the ant algorithms. Eastern-European Journal of Enterprise Technologies. 2019. Vol. 101, № 5/9. P. 25-34. DOI: https://doi.org/10.15587/1729-4061.2019.177817. 
Stage III. Generation of the initial positions of the ants on the original geospatial image. Generation of initial positions is performed only at the first iteration of the method using a random number generator.

In this case, the total number of ants is equal to the total number of pixels in the original geospatial image.

Stage IV. Calculation of length of the current section of each ant's motion. Calculated as taking into account the difference in the brightness of neighboring pixels for the $m$-th ant at the $i$-th image point on the $j$-th iteration;

Stage V. Calculation of route attractiveness. The attractiveness of the section of route $L_{i}^{m}(j)$ for $m$-th ant at the $i$-th image's point on the $j$-th iteration inversely depends on the length of the section of the route.

Stage VI. Pheromone concentration renewal.

At each iteration, the $m$ ants look for solutions and update the pheromone along the route.

At the beginning of the iterative process of the method on all sections of the route, the amount of pheromone is taken equal to a certain small amount. This value is determined in step II and is constant throughout the entire operation of the method. After each iteration, the concentration of pheromones changes in the areas selected by the ants.

As a result of carrying out a certain number of iterations of the method, routes are determined that are most attractive according to the selected criterion. On unattractive routes, the pheromone gradually disappears. As a result, unsightly routes disappear in this way.

Stage VII. Calculation of transitions probability.

Stage VIII. Calculation of fitness function $\varphi\left(\mathbf{X}_{i j}\right)$ for each $i$-th ant on the $j$-th iteration.

At each iteration, the $m$ agents look for solutions and update the pheromone along the route.

Each $m$-th agent:

- starts its way from the starting point of the route;

- sequentially passes all the points selected with the help of this method (turning points of the route);

- ends the path at one of the route's endpoints.

The movement of agents occurs according to the criterion of the minimum of the fitness function.

Stage IX. Verification of the fulfillment of the criteria for stopping work. The stopping criterion can be: 
- reaching the maximum permissible number of iterations of the iterative process;

- finding the necessary solution;

- no significant improvement in the value of the objective function for a certain number of iterations.

If one of the listed conditions is met, then the method proceeds to the next stage and the resulting image is displayed. Otherwise, there is a transition to stage VIII to the calculation of the fitness function.

Stage X. Determination of the coordinates of the optimal route of each ant.

Stage XI. The output of the rezult image.

Stage XII. The end of the method.

The result of the image processing method of the improved method based by the ant colony optimizationis the following: determination of the coordinates of the position of ants, at which the value of the fitness function will be maximum or minimum.

A visual assessment of the work of this method makes it easy to identify objects on the resulting image. This method of processing geospatial images by the ant colony optimization selects only the contours of objects on the original geospatial image.

\section{CONCLUSIONS}

Today, during the conduct of hostilities in the territory of Donetsk and Luhansk regions, numerous environmental problems arise. To solve these problems, high-resolution satellites and Earth remote sensing systems are used. This is due to the possibility of unimpeded receipt of species information on objects and areas of interest, as well as the fact that the necessary information is obtained remotely. The information received in real time after processing, in turn, allows making management decisions in the temporarily occupied territories.

Thus, when making decisions in environmental monitoring of temporarily occupied territories in Donetsk, Luhansk regions and Crimea using geospatial information, it is advisable to use a decision support system. This is due to the fact that such a decision support system provides an independent and thorough analysis of a given subject area when making decisions in difficult conditions. Methods of category theory are selected that allow using such mathematical constructions as statements, predicates, and the like in the form of category objects.

A method has been developed to support decision-making in environmental monitoring of temporarily occupied territories using 
geospatial information, mathematical constructions of the theory of categories and logic of predicates, which reflect the attitude in a structured and logical form. At different stages of the developed method, it is proposed to use algorithms and methods of swarm intelligence.

The use of two methods of swarm intelligence for image processing is considered. The result of the work of these methods is the selected objects of interest, which are input data into the database of the proposed method of decision support for environmental monitoring of temporarily occupied territories using geospatial information. For the task of detecting compact objects, it is proposed to use the method of an artificial bee colony. For the problem of detecting extended objects, it is proposed to use a method based by the ant algorithm. In the case when nothing is known in advance about the terrain and objects of interest, then it is necessary to use these swarm methods in parallel.

The direction of further research is to check the feasibility of the options for decisions proposed by this decision support system in the field of environmental monitoring of the temporarily occupied territories.

\section{SUMMARY}

The paper proposes the use of geospatial information for decisionmaking in environmental monitoring of temporarily occupied territories in Donetsk, Luhansk regions and Crimea. The sequence of actions of the decision support method for environmental monitoring of temporarily occupied territories using geospatial information, mathematical constructions of category theory and predicate logic is proposed. The order of implementation of the sequence of actions of this method is presented. It is proposed to additionally use the methods of swarm intelligence presented by the module in the decision support system when processing input data.

Swarm intelligence methods are also proposed to be used as supporting software for processing geospatial information. For the task of detecting compact objects, it is proposed to use the method based by the artificial bee colony. For the problem of detecting extended objects, it is proposed to use a method based by ant colony optimization. In the case when nothing is known in advance about the terrain and objects of interest, then it is necessary to use these swarm methods in parallel. The result of these methods is the selected objects of interest, which are input data into the database of the proposed decision support method for environmental monitoring of temporarily occupied territories using geospatial information. 


\section{REFERENCES}

1. Каракеян В.И. Мониторинг загрязнения окружающей среды. Москва : Юрайт, 2016. 397 с.

2. Fu W., Ma J., Chen P., Chen F. Remote Sensing Satellites for Digital Earth. In: Guo H., Goodchild M.F., Annoni A. (eds) Manual of

Digital Earth. Springer, Singapore. 2020. P. 55-123. URL: https:// doi.org/10.1007/978-981-32-9915-3_3.

3. Бутко I.M. Використання інформації дистанційного зондування в інтересах реінтеграції тимчасово окупованих територій. Управління та адміністрування в умовах протидї гібридним загрозам національній безпещі : Матеріали I Всеукраїнської науковопрактичної конференції (м. Київ, 7 грудня 2020 р.). Київ : ДУІТ, 2020. C. 111-113.

4. Бутко I.М., Худов Г.В., Хижняк І.А. Використання інформації геоінформаційних систем для оцінки стану земельного фонду на тимчасово окупованих територіях. Наука, техніка $i$ технологіï: актуальні питання та дослідження : тези допов. міжнар. наук-практ. конф., 12-13 бер. 2021 р. : Прага, 2021. С. 13-17.

5. Khaustov I.A., Rylev S.S., Kovaleva E.N. Development and application of modern geographic information systems for monitoring the environmental status of objects. Proceedings of the Voronezh State University of Engineering Technologies. 2019. № 81 (4). P. 263-267. (In Russ.) URL: https://doi.org/10.20914/2310-1202-2019-4-263-267.

6. Bidyuk P.I., Korshevnyuk L.O. Design of computer information systems for decision support, NTUU “KPI”, Kyiv. 2010. 340 p.

7. Hou J., Yuan Y., Peitao W., Zhiyuan R., Xiaojuan L. Development of a decision support system for tsunami evacuation: application to the Jiyang District of Sanya city in China. Nat. Hazards Earth Syst. Sci. 2017. P. 335-343.

8. Butko I. The Use of Geospatial Information by Public Authorities to Support the Decision Making of Management. Advanced Information Systems. 2021. № 5 (1). P. 39-44. DOI: https://doi.org/10.20998/25229052.2021.1.05.

9. Terelyansky P.V. Decision support systems. Experience of design. Volga State Techn. Univ, Volgograd. 2009. 127 p.

10. Кухар М.А. Алгоритм функціонування системи підтримки прийняття рішень в земельних відносинах. Інформатика та математичні методи в моделюванні. 2017 . № 7 (4). С. 325-332.

11. Бутко I.M. Формалізація технології використання геопросторових структур в системах обробки геопросторової інформації. 
Системи управління, навігації та зв'язку. 2021. № 1 (63). С. 17-22. DOI: https://doi.org/10.26906/SUNZ.2021.1.017.

12. Худов Г.В., Бутко I.М. Розробка методу підтримки прийняття рішення при реінтеграції тимчасово окупованих територій 3 використанням інформації систем дистанційного зондування Землі. Новітні технології - для захисту повітряного простору : 17 міжнар. наук. конф., 15-16 квіт. 2021 р. : тези допов. Харків, 2021. С. 575.

13. Худов Г.В., Шамрай Н.М. Використання інформації з систем повітряного та космічного базування для вирішення завдань екологічного моніторингу. Новітні технології - для захисту повітряного простору : 17 міжнар. наук. конф., 15-16 квіт. 2021 р. : тези допов. Харків, 2021. С. 569-570.

14. Лубко Д.В., Шаров С.В. Методи та системи штучного інтелекту: навчальний посібник. Мелітополь : ФОП Однорог Т.В. 2019. 264 c.

15. Ruban I, Khudov H., Makoveichuk O., Khizhnyak I., Khudov V., Podlipaiev V., Shumeiko V., Atrasevych O., Nikitin A., Khudov R. Segmentation of opticalelectronic images from on-board systems of remote sensing of the Earth by the artificial bee colony method. EasternEuropean Journal of Enterprise Technologies. 2019. Vol. 98. № 2/9. P. 37-45. DOI: https://doi.org/10.15587/1729-4061.2019.161860.

16. Ruban I., Khudov H., Makoveichuk O., Chomik M., Khudov V., Khizhnyak I., Podlipaiev V., Sheviakov Y., Baranik O., Irkha A. Construction of methods for determining the contours of objects on tonal aerospace images based on the ant algorithms. Eastern-European Journal of Enterprise Technologies. 2019. Vol. 101. № 5/9. P. 25-34. DOI: https://doi.org/10.15587/1729-4061.2019.177817.

\section{Information about the authors: \\ Butko Ihor Mykolaiovych,}

Candidate of Technical Sciences, Associate Professor, Deputy Director General

State Enterprise "State Land Cadastre Center" 3, Narodnoho Opolchennia str., Kyiv, 03680, Ukraine

Shamrai Nazar Mykolaiovych, Researcher at the Scientific Center of the Air Force Ivan Kozhedub Kharkiv National Air Force University 77/79, Sumska str., Kharkiv, 61023, Ukraine 